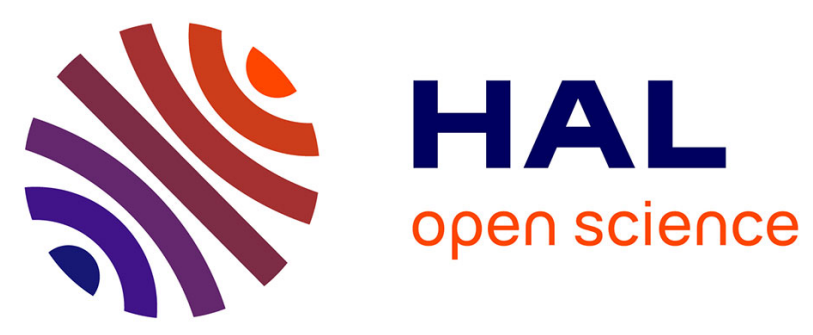

\title{
Lack of large genomic deletions in ,, and genes in negative familial breast cancer
}

\author{
Najim Ameziane, Ans M. W. Ouweland, Muriel A. Adank, Raymond N. C. P. \\ Vijzelaar, Abdellatif Errami, Josephine C. Dorsman, Hans Joenje, Hanne \\ Meijers-Heijboer, Quinten Waisfisz
}

\section{To cite this version:}

Najim Ameziane, Ans M. W. Ouweland, Muriel A. Adank, Raymond N. C. P. Vijzelaar, Abdellatif Errami, et al.. Lack of large genomic deletions in , and genes in negative familial breast cancer. Breast Cancer Research and Treatment, 2009, 118 (3), pp.651-653. 10.1007/s10549-009-0428-8 . hal00535370

\section{HAL Id: hal-00535370 \\ https://hal.science/hal-00535370}

Submitted on 11 Nov 2010

HAL is a multi-disciplinary open access archive for the deposit and dissemination of scientific research documents, whether they are published or not. The documents may come from teaching and research institutions in France or abroad, or from public or private research centers.
L'archive ouverte pluridisciplinaire HAL, est destinée au dépôt et à la diffusion de documents scientifiques de niveau recherche, publiés ou non, émanant des établissements d'enseignement et de recherche français ou étrangers, des laboratoires publics ou privés. 


\title{
Lack of large genomic deletions in BRIP1, PALB2, and FANCD2 genes in $B R C A 1 / 2$ negative familial breast cancer
}

\author{
Najim Ameziane - Ans M. W. van den Ouweland - Muriel A. Adank • \\ Raymond N. C. P. Vijzelaar · Abdellatif Errami · Josephine C. Dorsman · \\ Hans Joenje · Hanne Meijers-Heijboer · Quinten Waisfisz
}

Received: 20 May 2009/Accepted: 21 May 2009/Published online: 6 June 2009

(C) Springer Science+Business Media, LLC. 2009

\section{To the editor}

Breast cancer (BC) is the most common malignancy in women worldwide. It is estimated that $5-10 \%$ of all BC cases may be caused by germline mutations in breast cancer susceptibility genes [19, 21]. BRCA1 and BRCA2 are the major known $\mathrm{BC}$ susceptibility genes accounting for $\sim 16 \%$ of the familial BC cases [2]. Other BC susceptibility genes include TP53 [16], PTEN [15], ATM [24], LKB1/STK11 [8], CHEK2 [28], BRIP1/FANCJ [27], and $P A L B 2 / F A N C N$ [22]. However to date, the majority of familial $\mathrm{BC}$ cases can not be attributed to mutations in one of the known susceptibility genes.

The discovery of the breast cancer susceptibility gene BRCA2 as the gene defective in the Fanconi anemia (FA)-D1 complementation group [11], the identification of BRIPI (BRCA1 Interacting Protein) $[3,12,13]$ and PALB2 (Partner And Localizer of BRCA2) [23, 32] as the genes responsible for the FA-J and FA-N complementation groups, respectively, established a clear link between breast cancer susceptibility and FA. Fanconi anemia (FA) is a recessively

N. Ameziane - M. A. Adank · J. C. Dorsman · H. Joenje

H. Meijers-Heijboer · Q. Waisfisz ( $\square)$

Department of Clinical Genetics, Section Oncogenetics,

VU University Medical Center, Van der Boechorststraat 7, 1081 BT Amsterdam, The Netherlands

e-mail: q.waisfisz@vumc.nl

A. M. W. van den Ouweland

Department of Clinical Genetics, Erasmus Medical Center,

Westzeedijk 112, 3016 AH Rotterdam, The Netherlands

R. N. C. P. Vijzelaar · A. Errami

MRC-Holland, Willem Schoutenstraat 6, 1057 DN Amsterdam,

The Netherlands inherited chromosomal instability syndrome with autosomal or X-linked mode of inheritance, and is characterized by an increased susceptibility to several forms of malignancies [1, 17]. The disease is caused by mutations in one of the 13 genes so far identified [18]. The FA gene products interact in a common pathway whereby most of the proteins (FANCA, $\mathrm{B},-\mathrm{C},-\mathrm{E},-\mathrm{F},-\mathrm{G},-\mathrm{L}$, and -M) form a multiprotein complex that is required for the monoubiquitination of FANCD2 and FANCI. However, this modification step is not influenced by FANCD1 (BRCA2), FANCJ (BRIP1), or FANCN (PALB2), and hence these proteins seem to act downstream of this process. FANCD2 and FANCI are thought to form a protein complex (ID complex), which translocates to DNA damage sites where it co-localizes with the downstream FA proteins, BRCA2/FANCD1, BRIP1/FANCJ, and PALB2/FANCN and other proteins that are involved in the recognition and repair of DNA damage, such as BRCA1, ATM, NBS, and RAD51 [31].

Several studies explored whether heterozygous female carriers for a mutation in one of the FA genes are at increased risk for breast cancer. To date, only mutations in the "downstream" FA genes have been found to significantly elevate the risk of developing breast cancer. Heterozygous mutations in BRIPI/FANCJ and PALB2/FANCN appear to increase the risk 2- and 2.3-fold, respectively [22, 27]. Risk assessment has been based on screening for truncating mutations in these genes in familial breast cancer (FBC) patients lacking mutations in BRCA1/2. Furthermore, FANCD2 mutations, have been suggested to play a role in the development of breast cancer based on observations of Fancd2 knockout mice, which demonstrated a high incidence of epithelial tumors, including mammary and ovarian tumors [10]. However, in humans a significant contribution of FANCD2 mutations to $\mathrm{FBC}$ could not be established [14, 26]. 
Interestingly, one of the eight FA-N patients described in literature carried a pathogenic nucleotide substitution on one allele and a large genomic deletion encompassing exon 1 through 10 of PALB2/FANCN on the other allele [32]. The latter aberration is not detectable by standard sequencing methods applied for PALB2/FANCN mutation screening in most studies published to date $[4,5,7,9,22$, 29]. Although, large deletion analysis of $P A L B 2$ has been assayed in BC patients from French-Canadian and northern-Finnish ancestry, these cohorts were relatively small $[6,20]$. In addition, such genetic aberrations may be very rare in the analyzed populations. Analysis of large deletions in BRIP1/FANCJ and FANCD2 has not been previously described in literature.

Since large deletion mutations have not been extensively studied, we hypothesized that such aberrations in the downstream FA genes (FANCJ and FANCN) and FANCD2 may contribute to the risk of breast cancer in familial cases. In the current study, we analyzed a total of 716 unrelated Dutch $B R C A 1 / 2$ negative familial breast cancer patients (inclusion criteria have described elsewhere [30] for large genomic deletions in, BRIPI/FANCJ, PALB2/FANCN, and FANCD2 using Multiplex Ligation-dependent Probe Amplification (MLPA; [25]. We failed to detect deletions in any of these genes. The MLPA kits used for the analysis contained probes targeted against all the exons of BRIP1/FANCJ and PALB2/ $F A N C N$. Due to the presence of $F A N C D 2$ pseudogenes, only a number of $F A N C D 2$ exons could be analyzed (exons: 1, 2, $4,9,12,17,19,23,28,32,35,41,43)$ by MLPA. Large deletions encompassing multiple exons will be detected by the used MLPA kits, but subtle deletions/amplifications in the intronic regions and of FANCD2 exons of which no probes were present in the MLPA kit could have been missed. In addition, genetic rearrangements such as inversions are not detectable by MLPA.

Our results suggest that large genomic deletions in BRIP1/FANCJ, PALB2/FANCN, and FANCD2 do not contribute significantly to the FBC risk in the Dutch population. In addition, no large deletions in PALB2/FANCN were observed in two previous studies where 43 FBC patients of French-Canadian ancestry [6] and 61 index patients of breast and/or ovarian cancer families from Northern Finland [20] were analyzed. The only known FA patient with a large deletion in PALB2/FANCN is of Argentinean nationality, this mutation might be derived from a founder of this particular population [32]. It may therefore be of interest to test FBC patients from the same population for the presence of this large deletion. Altogether, large genomic rearrangements in the studied genes may be very rare and the analysis of additional large cohorts of FBC patients from different populations may be necessary to determine the contribution of such aberrations to breast cancer risk.

\section{References}

1. Alter BP (2003) Cancer in Fanconi anemia, 1927-2001. Cancer 97:425-440. doi:10.1002/cncr.11046

2. Anglian Breast Cancer Study Group (2000) Prevalence and penetrance of BRCA1 and BRCA2 mutations in a populationbased series of breast cancer cases. Anglian Breast Cancer Study Group. Br J Cancer 83:1301-1308. doi:10.1054/bjoc.2000.1407

3. Bridge WL, Vandenberg CJ, Franklin RJ et al (2005) The BRIP1 helicase functions independently of BRCA1 in the Fanconi anemia pathway for DNA crosslink repair. Nat Genet 37:953-957. doi:10.1038/ng1627

4. Cao AY, Huang J, Hu Z et al (2009) The prevalence of PALB2 germline mutations in BRCA1/BRCA2 negative Chinese women with early onset breast cancer or affected relatives. Breast Cancer Res Treat 114:457-462. doi:10.1007/s10549-008-0036-Z

5. Erkko H, Xia B, Nikkila J et al (2007) A recurrent mutation in PALB2 in Finnish cancer families. Nature 446:316-319. doi: 10.1038/nature05609

6. Foulkes WD, Ghadirian P, Akbari MR et al (2007) Identification of a novel truncating PALB2 mutation and analysis of its contribution to early-onset breast cancer in French-Canadian women. Breast Cancer Res 9:R83. doi:10.1186/bcr1828

7. Garcia MJ, Fernandez V, Osorio A et al (2008) Analysis of FANCB and FANCN/PALB2 Fanconi anemia genes in BRCA1/ 2-negative Spanish breast cancer families. Breast Cancer Res Treat 113:545-551. doi:10.1007/s10549-008-9945-0

8. Giardiello FM, Brensinger JD, Tersmette AC et al (2000) Very high risk of cancer in familial Peutz-Jeghers syndrome. Gastroenterology 119:1447-1453. doi:10.1053/gast.2000.20228

9. Gunnarsson H, Arason A, Gillanders EM et al (2008) Evidence against PALB2 involvement in Icelandic breast cancer susceptibility. J Negat Results Biomed 7:5. doi:10.1186/1477-5751-7-5

10. Houghtaling S, Timmers C, Noll M et al (2003) Epithelial cancer in Fanconi anemia complementation group D2 (Fancd2) knockout mice. Genes Dev 17:2021-2035. doi:10.1101/gad.1103403

11. Howlett NG, Taniguchi T, Olson S et al (2002) Biallelic inactivation of BRCA2 in Fanconi anemia. Science 297:606-609. doi: 10.1126/science. 1073834

12. Levitus M, Waisfisz Q, Godthelp BC et al (2005) The DNA helicase BRIP1 is defective in Fanconi anemia complementation group J. Nat Genet 37:934-935. doi:10.1038/ng1625

13. Levran O, Attwooll C, Henry RT et al (2005) The BRCA1interacting helicase BRIP1 is deficient in Fanconi anemia. Nat Genet 37:931-933. doi:10.1038/ng 1624

14. Lewis AG, Flanagan J, Marsh A et al (2005) Mutation analysis of FANCD2, BRIP1/BACH1, LMO4 and SFN in familial breast cancer. Breast Cancer Res 7:R1005-R1016. doi:10.1186/ bcr1336

15. Lynch ED, Ostermeyer EA, Lee MK et al (1997) Inherited mutations in PTEN that are associated with breast cancer, cowden disease, and juvenile polyposis. Am J Hum Genet 61:1254-1260. doi:10.1086/301639

16. Malkin D, Li FP, Strong LC et al (1990) Germ line p53 mutations in a familial syndrome of breast cancer, sarcomas, and other neoplasms. Science 250:1233-1238. doi:10.1126/science.1978757

17. Mathew CG (2006) Fanconi anaemia genes and susceptibility to cancer. Oncogene 25:5875-5884. doi:10.1038/sj.onc.1209878

18. Meijer GA (2007) The 13th Fanconi anemia gene identified: FANCI-importance of the 'Fanconi anemia pathway' for cellular oncology. Cell Oncol 29:181-182

19. Oldenburg RA, Meijers-Heijboer H, Cornelisse CJ et al (2007) Genetic susceptibility for breast cancer: how many more genes to be found? Crit Rev Oncol Hematol 63:125-149. doi:10.1016/j. critrevonc.2006.12.004 
20. Pylkas K, Erkko H, Nikkila J et al (2008) Analysis of large deletions in BRCA1, BRCA2 and PALB2 genes in Finnish breast and ovarian cancer families. BMC Cancer 8:146. doi:10.1186/ 1471-2407-8-146

21. Rahman N, Scott RH (2007) Cancer genes associated with phenotypes in monoallelic and biallelic mutation carriers: new lessons from old players. Hum Mol Genet 16:60-66 Spec No 1:

22. Rahman N, Seal S, Thompson D et al (2007) PALB2, which encodes a BRCA2-interacting protein, is a breast cancer susceptibility gene. Nat Genet 39:165-167. doi:10.1038/ng 1959

23. Reid S, Schindler D, Hanenberg $\mathrm{H}$ et al (2007) Biallelic mutations in PALB2 cause Fanconi anemia subtype FA-N and predispose to childhood cancer. Nat Genet 39:162-164. doi:10.1038/ ng 1947

24. Renwick AD, Thompson S, Seal P et al (2006) ATM mutations that cause ataxia-telangiectasia are breast cancer susceptibility alleles. Nat Genet 38:873-875. doi:10.1038/ng1837

25. Schouten JP, McElgunn CJ, Waaijer R et al (2002) Relative quantification of 40 nucleic acid sequences by multiplex ligationdependent probe amplification. Nucleic Acids Res 30:e57. doi: 10.1093/nar/gnf056

26. Seal S, Barfoot R, Jayatilake H et al (2003) Evaluation of Fanconi anemia genes in familial breast cancer predisposition. Cancer Res 63:8596-8599
27. Seal S, Thompson D, Renwick A et al (2006) Truncating mutations in the Fanconi anemia J gene BRIP1 are low-penetrance breast cancer susceptibility alleles. Nat Genet 38:1239-1241. doi: $10.1038 / n g 1902$

28. The CHEK2 Breast Cancer Case-Control Consortium (2004) CHEK2*1100delC and susceptibility to breast cancer: a collaborative analysis involving 10,860 breast cancer cases and 9, 065 controls from 10 studies. Am J Hum Genet 74:1175-1182. doi: $10.1086 / 421251$

29. Tischkowitz M, Sabbaghian N, Ray AM et al (2008) Analysis of the gene coding for the BRCA2-interacting protein PALB2 in hereditary prostate cancer. Prostate 68:675-678. doi:10.1002/ pros. 20729

30. Van der Hout AH, van den Ouweland AM, van der Luijt RB et al (2006) A DGGE system for comprehensive mutation screening of BRCA1 and BRCA2: application in a Dutch cancer clinic setting. Hum Mutat 27:654-666. doi:10.1002/humu.20340

31. Wang W (2007) Emergence of a DNA-damage response network consisting of Fanconi anaemia and BRCA proteins. Nat Rev Genet 8:735-748. doi:10.1038/nrg2159

32. Xia B, Dorsman JC, Ameziane N et al (2007) Fanconi anemia is associated with a defect in the BRCA2 partner PALB2. Nat Genet 39:159-161. doi: $10.1038 / n g 1942$ 